\title{
Studying the oxidation of water to molecular oxygen in photosynthetic and artificial systems by time-resolved membrane-inlet mass spectrometry
}

\author{
Dmitriy Shevela * and Johannes Messinger* \\ Department of Chemistry, Chemistry Biology Centre, Umeå University, Umeå, Sweden
}

Edited by:

Suleyman I. Allakhverdiev, Russian

Academy of Sciences, Russia

\section{Reviewed by:}

Mohammad M. Najafpour, Institute

for Advanced Studies in Basic

Sciences, Iran

Harvey J. M. Hou, Alabama State

University, USA

\section{*Correspondence:}

Dmitriy Shevela and Johannes

Messinger, Department of

Chemistry, Chemistry Biology

Centre, Umeå University, Linnaeus

Väg 6, S-90187 Umeå, Sweden

e-mail:dmitriy.shevela@

chem.umu.se;

johannes.messinger@chem.umu.se

\section{INTRODUCTION}

In nature, the splitting of water to molecular oxygen $\left(\mathrm{O}_{2}\right)$ is catalyzed by the membrane-bound pigment-protein photosystem II (PSII) of plants, algae, and cyanobacteria (Vinyard et al., 2013). The catalytic site of the water-splitting reaction is an inorganic tetra-manganese mono-calcium penta-oxygen $\left(\mathrm{Mn}_{4} \mathrm{CaO}_{5}\right)$ cluster (Figure 1) that forms, together with its protein ligands, the water-oxidizing complex (WOC) of PSII (Yano et al., 2006; Umena et al., 2011). Water-splitting by the $\mathrm{Mn}_{4} \mathrm{CaO}_{5}$ cluster is energetically driven by the strongest biological oxidant, $\mathrm{P}_{680}{ }^{+}$(with a midpoint potential of $\sim 1.25 \mathrm{~V}$ ), generated by the light-induced charge separation within the Chl-containing reaction center (RC) of PSII (Diner and Rappaport, 2002; Ishikita et al., 2005). A redox-active tyrosine residue $\left(\mathrm{Y}_{\mathrm{Z}}\right)$ is the essential electron transfer intermediate between the photoactive RC and the $\mathrm{Mn}_{4} \mathrm{CaO}_{5}$ cluster of PSII. Following light absorption, the $\mathrm{Mn}_{4} \mathrm{CaO}_{5}$ cluster is oxidized step-wise (one electron at a time) and thereby cycles through five redox states, known as $S_{i}$ states (where $i$ reflects the number of oxidizing equivalents stored by the cluster) (Figure 1). The four-electron four-proton oxidation chemistry of two water molecules is completed when the four oxidizing equivalents are accumulated within the WOC, and the highly reactive $S_{4}$ state relaxes into the most reduced $S_{0}$ state with the concomitant $\mathrm{O}-\mathrm{O}$ bond formation and release of $\mathrm{O}_{2}$ (Messinger et al., 2012; Cox and Messinger, 2013). This reaction cycle of water oxidation is also known as the Kok cycle (Kok et al., 1970).

Abbreviations: $\mathrm{C}_{\mathrm{i}}$, inorganic carbon $\left(\mathrm{CO}_{2}, \mathrm{H}_{2} \mathrm{CO}_{3}, \mathrm{HCO}_{3}^{-}, \mathrm{CO}_{3}^{2-}\right)$; Chl, chlorophyll; PSII, photosystem II; RC, reaction center; WOC, water-oxidizing complex.
During the last few decades an enormous progress in elucidation of the WOC structure and in understanding the mechanism of the water-splitting became possible due to employment of numerous biophysical techniques (summarized in Aartsma and Matysik, 2008; Messinger et al., 2009a,b; also see refs therein). Among them, time-resolved isotope-ratio membrane-inlet mass spectrometry (TR-IR-MIMS) in combination with isotope labeling (Konermann et al., 2008; Beckmann et al., 2009) provided the most direct information on the $\mathrm{S}_{i}$ state dependent substrate water binding to the WOC (Messinger et al., 1995; Wydrzynski et al., 1996). These findings were recently reviewed in detail by Hillier and Wydrzynski (2008), Messinger et al. (2012), and Cox and Messinger (2013) and are, therefore, only briefly discussed here. However, TR-MIMS has also been successfully employed and yielded important data on other structural and mechanistic aspects of the water-splitting chemistry in both natural PSII and in variously designed artificial $\mathrm{O}_{2}$-evolving catalysts. In this minireview, we summarize these recent investigations and also provide some comments on perspectives of the TR-MIMS technique for future studies of water-splitting and $\mathrm{O}_{2}$ evolution.

\section{KEY CONCEPTS OF TR-MIMS}

The concept of TR-MIMS was first applied in 1963, when Georg Hoch and Bessel Kok began to use mass spectrometer with a semipermeable membrane as inlet system (Hoch and Kok, 1963). This allowed to separate the liquid sample from the high vacuum space of the mass spectrometer, while at the same time it was permeable to the gaseous analytes. This excellent solution allowed continuous on-line measurements of dissolved gaseous analytes (either dissolved in solution or directly from the gas phase) with a temporal resolution of a few seconds. Therefore, 


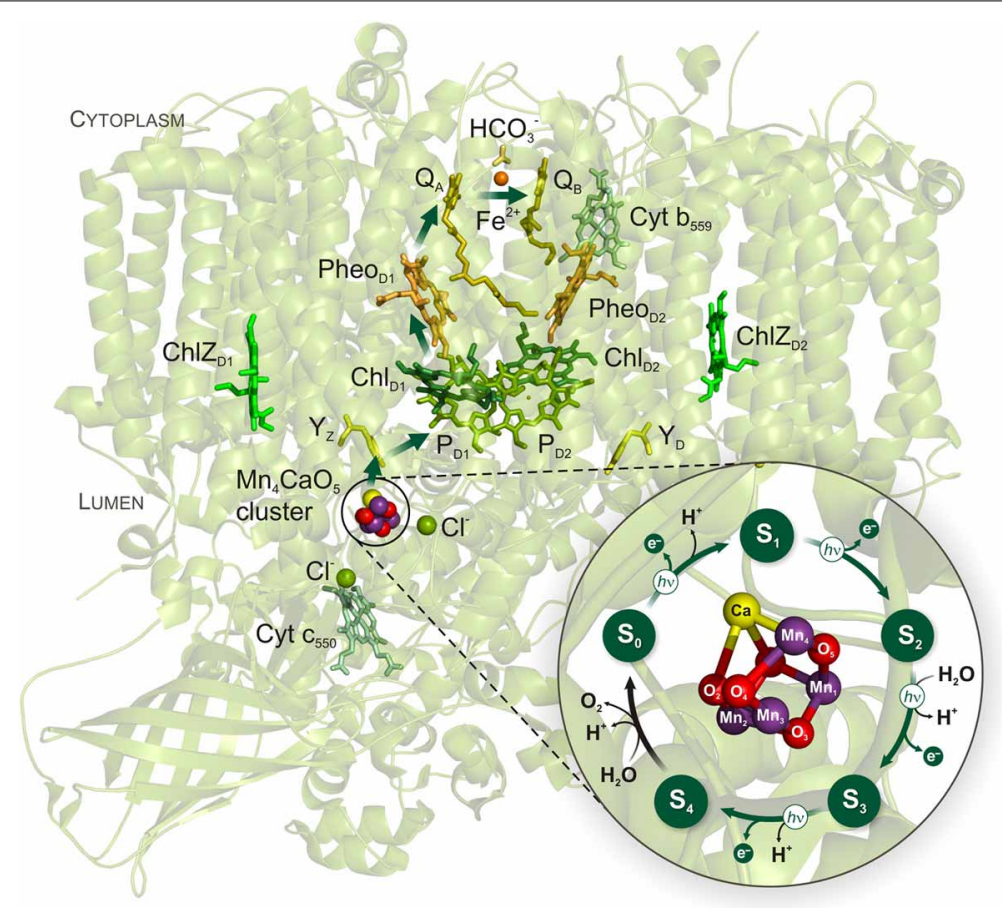

FIGURE 1 | Cyanobacterial PSII structure and Kok cycle of photosynthetic water oxidation by the $\mathrm{Mn}_{4} \mathrm{CaO}_{5}$ cluster. The arrows within PSII indicate the direction of electron transfer which comprises the following redox-active cofactors: inorganic $\mathrm{Mn}_{4} \mathrm{CaO}_{5}$ cluster, redox-active tyrosine $\mathrm{Z}\left(\mathrm{Y}_{\mathrm{Z}}\right)$, the primary electron donor $\mathrm{P} 680$ that includes a pair of Chls a $\left(P_{D 1}\right.$ and $\left.P_{D 2}\right)$ and two accessory Chls $\left(C_{D 1}\right.$ and $\left.C h l_{D 2}\right)$, the primary pheophytin $\left(\right.$ Pheo $\left._{D 1}\right)$ acceptor, the primary $\left(\mathrm{Q}_{A}\right)$ and the secondary
$\left(\mathrm{Q}_{\mathrm{B}}\right)$ quinone acceptors. The phytyl tails of the Chl's and Pheo's, and the isoprenyl chains of the quinones have been cut for clarity. The light-induced $\mathrm{S}$ state transitions of the $\mathrm{Mn}_{4} \mathrm{CaO}_{5}$ cluster are indicated by arrows with " $h v$ " labels. The PSII structure and the zoomed structural model of the $\mathrm{Mn}_{4} \mathrm{CaO}_{5}$ cluster in the center of the Kok cycle are based on the recent PSII crystal structure at a resolution of $1.9 \AA$ (PDB entry 3ARC; Umena et al., 2011). the TR-MIMS technique is ideally suited for investigations of photosynthetic and artificial water-oxidation $/ \mathrm{O}_{2}$ evolution (for instance, see Konermann et al., 2008; Beckmann et al., 2009). For an outline of other TR-MIMS applications in biological and in industrial systems, see reviews by Lauritsen and Kotiaho (1996) and Johnson et al. (2000). Recent technological advances in MIMS instrumentation are summarized in Davey et al. (2011).

A schematic view of a TR-MIMS set-up employing an isotope ratio mass spectrometer is shown in Figure 2. This type of mass spectrometers is normally equipped with an electronimpact ion source, magnetic sector field analyzer, and individual detectors (Faraday cups) that provide simultaneous detection of several masses (ions) with high sensitivity and signal stability. For its ability to monitor and to selectively analyze all isotopologues (molecules that differ only in their isotopic composition) of gaseous products with one instrument, the TR-MIMS approach in combination with isotope enrichments became indispensable tool for kinetic and functional analyses of photosynthetic enzymes (Konermann et al., 2008; Beckmann et al., 2009). The key part of the TR-MIMS instrument is a gas inlet system that is integrated within a MIMS cell. The design of MIMS cells may vary depending on the measuring purposes (Konermann et al., 2008; Beckmann et al., 2009), but all of them contain a gaspermeable membrane functioning as analyte inlet system into the vacuum of the mass spectrometer. The coupling of such a cell to various light sources (e.g., Xenon lamps or lasers) allows carrying out the measurements of light-induced $\mathrm{O}_{2}$ evolution in photosynthetic samples or light-driven $\mathrm{O}_{2}$-evolving artificial catalysts. Before entering the ion source of the mass spectrometer the analytes pass through a cryogenic trap (Figure 2), which freezes out water vapor that inadvertently pervaporate through the membrane in trace amounts.

Enrichment of aqueous sample suspension with oxygen's heavy isotope $\left({ }^{18} \mathrm{O}\right)$ for isotope ratio measurements of $\mathrm{O}_{2}$ (and/or $\mathrm{CO}_{2}$ ) isotopologues is a powerful and commonly used tool in studies of water-splitting chemistry and/or related reactions. Therefore, most of the experiments are carried out in $\mathrm{H}_{2}^{18} \mathrm{O}$ labeled sample suspensions/solutions.

\section{IS WATER THE IMMEDIATE SUBSTRATE OF PHOTOSYNTHETIC $\mathrm{O}_{2}$ EVOLUTION?}

It is widely accepted that water is the immediate substrate for photosynthetic $\mathrm{O}_{2}$ production. However, Metzner (1978) suggested that instead hydrogen carbonate (bicarbonate; $\mathrm{HCO}_{3}^{-}$) is the immediate substrate for $\mathrm{O}_{2}$ formation that is subsequently replenished by the reaction of $\mathrm{CO}_{2}$ with $\mathrm{H}_{2} \mathrm{O}$. This hypothesis was discounted for long because the isotopic equilibration between ${ }^{18} \mathrm{O}$-water and $\mathrm{HCO}_{3}^{-}$is too slow to account for early isotope labeling studies (Ruben et al., 1941; Stemler and Radmer, 1975; Stevens et al., 1975; Radmer and Ollinger, 1980). Due to the discovery that a carbonic anhydrase (CA) activity is associated with PSII (Lu and Stemler, 2002; Villarejo et al., 2002; Moskvin et al., 2004) the "bicarbonate-as-substrate hypothesis" needed to be re-investigated with refined expriments. Indeed, due to rapid 
exchange of $\mathrm{HCO}_{3}^{-}$and $\mathrm{CO}_{2}$ species by $\mathrm{CA}$, the ${ }^{18} \mathrm{O}$-label could "escape" from $\mathrm{HCO}_{3}^{-}$to water (which has a several orders higher concentration than the added ${ }^{18} \mathrm{O}$-labeled $\mathrm{HCO}_{3}^{-}$), and, thus, lead to the lack of $\mathrm{O}_{2}$ yield from $\mathrm{HCO}_{3}^{-}$(Stemler and Radmer, 1975; Radmer and Ollinger, 1980).

Two different TR-MIMS approaches were taken recently and both exclude that $\mathrm{HCO}_{3}^{-}$is a physiologically significant substrate (Clausen et al., 2005a; Hillier et al., 2006). Clausen et al. (2005a) reported that under $\mathrm{H}_{2}^{18} \mathrm{O}$-labeled and $\mathrm{CO}_{2} / \mathrm{HCO}_{3}^{-}$-depleted conditions the typical oscillation pattern of ${ }^{18} \mathrm{O}$-enriched $\mathrm{O}_{2}$ evolution is obtained in response to single light flashes, but didn't find any evidence for $\mathrm{CO}_{2}$ release. The latter would be expected in case the Metzner's hypothesis would be correct. Hillier et al. (2006), in their TR-MIMS study, employed ${ }^{18} \mathrm{O} /{ }^{13}$ C-labeled $\mathrm{HCO}_{3}^{-}$to probe the capability of PSII (from higher plants and cyanobacteria) to oxidize $\mathrm{HCO}_{3}^{-}$. The authors were able to detect an extremely small (and, thus, non-physiological) flux of ${ }^{18} \mathrm{O}$ from $\mathrm{HCO}_{3}^{-}$into $\mathrm{O}_{2}$ similar to that observed in an early TR-MIMS study of Radmer and Ollinger (1980). Moreover, no relationship between $\mathrm{O}_{2}$ evolution and PSII-associated CA activity was found by McConnell et al. (2007) in their TR-MIMS examination of PSII preparations from higher plants.

\section{IS HYDROGEN CARBONATE A LIGAND TO THE WOC?}

Hydrogen carbonate had been proposed to bind as integral cofactor to the $\mathrm{Mn}_{4} \mathrm{CaO}_{5}$ cluster after accumulation of many experimental results indicating: (i) the requirement of $\mathrm{HCO}_{3}^{-}$ions for optimal stability and functionality of the WOC (Van Rensen and Klimov, 2005), and (ii) it's important role for the photoassembly reaction of the $\mathrm{Mn}_{4} \mathrm{CaO}_{5}$ cluster (Dasgupta et al., 2008). Moreover, in the PSII crystal structure from Thermosynechococcus elongatus at $3.5 \AA$ resolution, $\mathrm{HCO}_{3}^{-}$was modeled as a nonprotein ligand bridging $\mathrm{Mn}$ and $\mathrm{Ca}$ ions within the WOC (Ferreira et al., 2004).

Earlier, interesting TR-MIMS experiments were performed by Stemler (1989) and Govindjee et al. (1991), in which formate

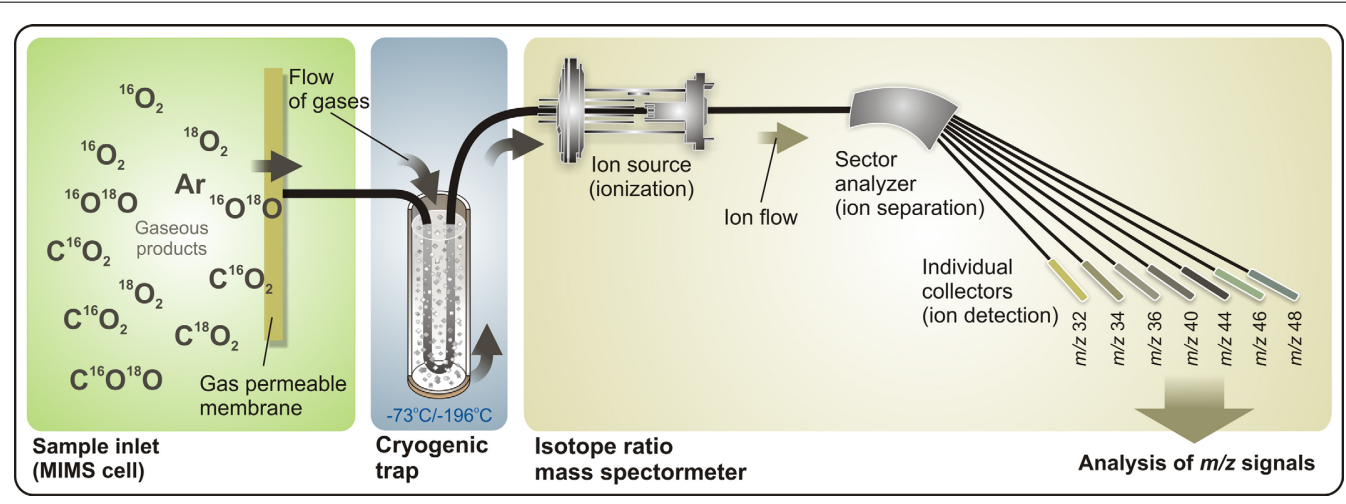

FIGURE 2 | Representation of a TR-IR-MIMS set-up. Gaseous products, produced by sample suspension (for instance, by PSII samples) in the cell, penetrate through a gas-permeable membrane into a high-vacuum space, pass through a cryogenic trap (which removes water vapor from a flow of gaseous analytes), and enter the isotope ratio mass spectrometer. Here, gaseous analytes are first ionized in the ion source by electron impact, and are then separated according to their $\mathrm{m} / \mathrm{z}$ ratios by a magnetic field in the sector analyzer that allows simultaneous online detection by individual collector cups (e.g., a 7-cup Faraday detector array). MS signals are monitored and analyzed using a personal computer. See text for further details.
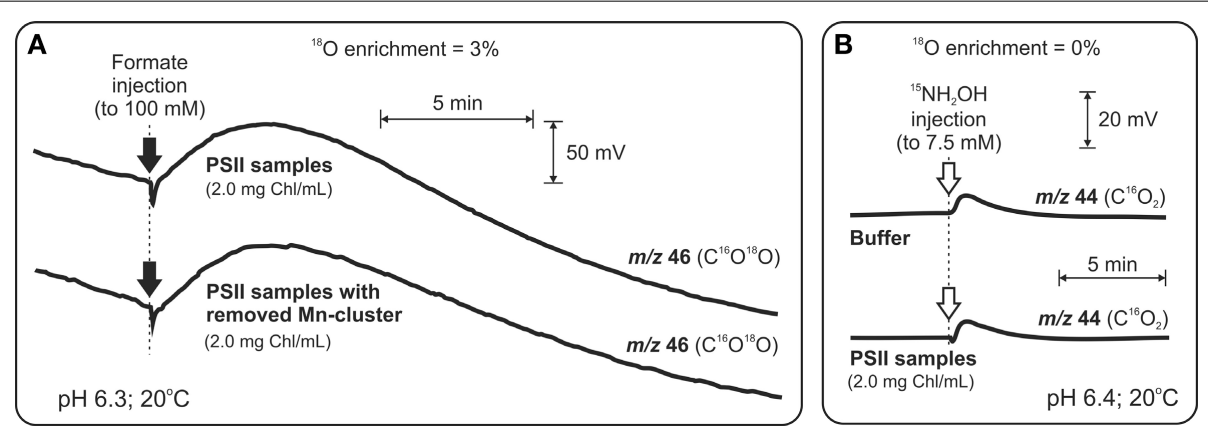

FIGURE 3 | TR-MIMS experiments demonstrating that $\mathrm{HCO}_{3}^{-}$is not a tightly bound ligand to the $\mathrm{Mn}_{4} \mathrm{CaO}_{5}$ cluster in spinach PSII membrane fragments. (A) Amount of released $\mathrm{CO}_{2}$ upon formate addition (black arrows) to intact PSII membranes is the same as in the case of PSII membranes without the $\mathrm{Mn}_{4} \mathrm{CaO}_{5}$ cluster (due to 75-min pre-incubation with $80 \mathrm{mM} \mathrm{N}_{2} \mathrm{H}_{4}$ ). Due to enrichment of sample suspension with $\mathrm{H}_{2}^{18} \mathrm{O}(3 \%)$ $\mathrm{CO}_{2}$ was detected as $\mathrm{C}^{16} \mathrm{O}^{18} \mathrm{O}$ at $\mathrm{m} / z$ 46. (B) Addition of the strong reductant $\mathrm{NH}_{2} \mathrm{OH}$ (white arrows) at concentrations known to cause rapid reduction of the $\mathrm{Mn}_{4} \mathrm{CaO}_{5}$ cluster and release of $\mathrm{Mn}$ ions as $\mathrm{Mn}^{\|}$into the solution didn't lead to a release of $\mathrm{CO}_{2} / \mathrm{HCO}_{3}^{-}$above background. In order to avoid the overlay of $\mathrm{CO}_{2}$ and $\mathrm{N}_{2} \mathrm{O}$ signals (the latter is known to be produced during interaction of $\mathrm{NH}_{2} \mathrm{OH}$ with the $\mathrm{Mn}_{4} \mathrm{CaO}_{4}$ cluster), the $\mathrm{N}_{2} \mathrm{O}$ signal was shifted from $\mathrm{m} / \mathrm{z} 44$ to $\mathrm{m} / \mathrm{z} 46$ by employing the ${ }^{15} \mathrm{~N}$-labeled $\mathrm{NH}_{2} \mathrm{OH}$ for these experiments. To facilitate equilibration between $\mathrm{CO}_{2}$ and $\mathrm{HCO}_{3}^{-}$all measurements were performed in the presence of externally added CA (to a final concentration of $3 \mu \mathrm{g} \mathrm{ml}^{-1}$ ). Modified from Shevela et al. (2008b). 
was tested to induce the release of $\mathrm{HCO}_{3}^{-}$(that can be detected by TR-MIMS as $\mathrm{CO}_{2}$ ) from PSII. Although Govindjee et al. (1991) provided clear evidence for the formate-induced release of $\mathrm{CO}_{2} / \mathrm{HCO}_{3}^{-}$, the $\mathrm{HCO}_{3}^{-}$binding site was not specified in this study. Based on numerous previous data indicating that $\mathrm{HCO}_{3}^{-}$ is a ligand to the non-heme iron (NHI) at the electron acceptor side of PSII, the released $\mathrm{CO}_{2}$ was suggested to derive from this binding site. However, later formate was shown to bind both at the acceptor and the donor (water-splitting) side of PSII (Feyziev et al., 2000), and therefore, the released $\mathrm{CO}_{2} / \mathrm{HCO}_{3}^{-}$could also originate from the water-splitting side.

In order to specifically probe the possible binding of $\mathrm{HCO}_{3}^{-}$ to the $\mathrm{Mn}_{4} \mathrm{CaO}_{5}$ cluster at the donor side of PSII, Shevela et al. $(2008 \mathrm{a}, \mathrm{b})$ re-examined and extended the earlier TR-MIMS investigations. Thus, a comparison of the formate-induced $\mathrm{C}^{16} \mathrm{O}^{18} \mathrm{O}$ yields (Figure 3A), under $\mathrm{H}_{2}^{18} \mathrm{O}$-enriched conditions, in intact PSII and Mn-depleted PSII was performed. This was complemented by experiments in which the gaseous products produced by a quick reductive destruction of the of the $\mathrm{Mn}_{4} \mathrm{CaO}_{5}$ cluster by ${ }^{15} \mathrm{~N}$-labeleld $\mathrm{NH}_{2} \mathrm{OH}$ (Figure 3B) were studied. Both approaches clearly demonstrated that the detected $\mathrm{CO}_{2} / \mathrm{HCO}_{3}^{-}$does not originate from the inorganic core of the water-splitting site of PSII (Shevela et al., 2008a,b). Independent evidence for absence of $\mathrm{HCO}_{3}^{-}$bound to the WOC was provided by FTIR and GS-MS experiments (Aoyama et al., 2008; Ulas et al., 2008). Moreover, in recent $\mathrm{x}$-ray crystallography studies at resolutions of 1.9-3.0 $\AA$ no $\mathrm{HCO}_{3}^{-}$was found in the vicinity of the $\mathrm{Mn}_{4} \mathrm{CaO}_{5}$ cluster, while they all clearly show $\mathrm{HCO}_{3}^{-}$bound to the NHI on the acceptor side of PSII (Guskov et al., 2010; Umena et al., 2011) (also, see Figure 1). Thus, it can be excluded that $\mathrm{HCO}_{3}^{-}$is a tightly bound ligand of the $\mathrm{Mn}_{4} \mathrm{CaO}_{5}$ cluster.

However, none of the mentioned studies negates the option that a mobile, weakly bound, and rapidly exchanging $\mathrm{HCO}_{3}^{-}$ affects the activity of the WOC. Thus, in case of the TR-MIMS measurements, weakly bound $\mathrm{HCO}_{3}^{-}$may have been removed during the required degassing of the MIMS cell prior to formate or $\mathrm{NH}_{2} \mathrm{OH}$ additions to PSII samples. Therefore, the possible loss of weakly bound $\mathrm{HCO}_{3}^{-}$and the amount of $\mathrm{HCO}_{3}^{-}$associated with PSII under air-saturated condition remain to be established in future TR-MIMS experiments.

\section{WHEN AND HOW DOES SUBSTRATE WATER BIND TO THE WOC?}

Indisputably, the most significant and unique contribution of the TR-MIMS instrumentation in understanding of water-oxidation mechanism in photosynthesis was its application for studying substrate binding in the different $S_{i}$ states of the WOC. In these experiments the binding of water to the WOC is probed by the rapid injection of $\mathrm{H}_{2}^{18} \mathrm{O}$ into the PSII samples which were preset into the desired $S_{i}$ state by pre-illumination with $0,1,2$, or 3 flashes. Then, after desired incubation times, $\mathrm{O}_{2}$ evolution is induced by a sequence of additional flashes. The exchange rates of the two substrate molecules are then calculated from the change of the ${ }^{16} \mathrm{O}^{18} \mathrm{O}$ and ${ }^{18} \mathrm{O}^{18} \mathrm{O}$ yields as a function of incubation time (see Figure 4A for protocol of the TR-MIMS measurements of substrate water exchange in the $S_{3}$ state). The mixing time of $\mathrm{H}_{2}^{18} \mathrm{O}$ with the PSII samples after injection and a very low level of dissolved $\mathrm{O}_{2}$ in $\mathrm{H}_{2}^{18} \mathrm{O}$ are highly important for these experiments

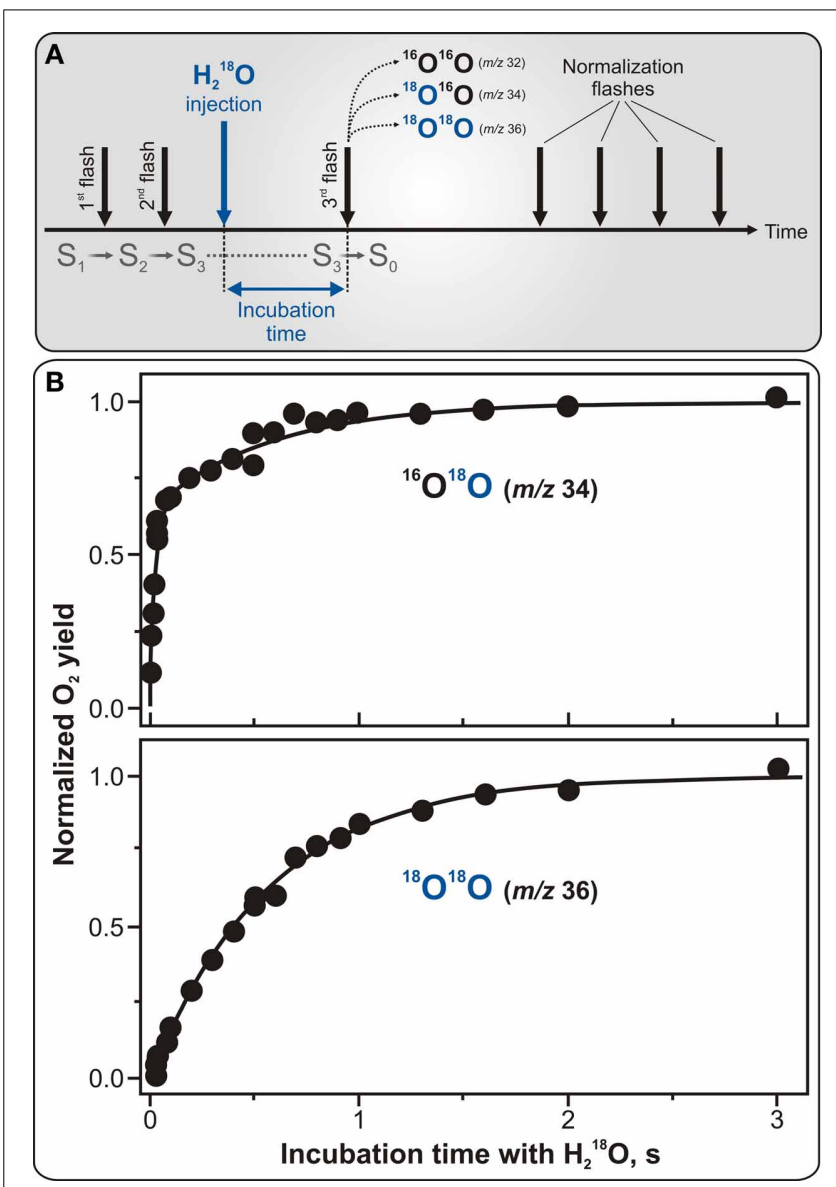

FIGURE 4 | Protocol for TR-MIMS measurements of $\mathrm{H}_{2}^{16} \mathrm{O} / \mathrm{H}_{2}^{18} \mathrm{O}$ exchange in the $S_{3}$ state of PSII (A) and experimentally obtained substrate water exchange rates in spinach thylakoids (B). (A) The $S_{3}$ state is populated by two pre-flashes given at $2 \mathrm{~Hz}$ (shown by the two first black vertical arrows). This is followed by the rapid injection of $\mathrm{H}_{2}^{18} \mathrm{O}$ into the PSII sample (shown by blue vertical arrow) and subsequent fast mixing of the injected $\mathrm{H}_{2}^{18} \mathrm{O}$ with the sample. Evolution of $\mathrm{O}_{2}$ isotopologues is then induced by a 3rd flash, given at varying delay times (from 0 to $10 \mathrm{~s}$ ) after the $\mathrm{H}_{2}^{18} \mathrm{O}$ injection (signified as incubation time). Finally, a series of four flashes is given at $2 \mathrm{~Hz}$ to induce $\mathrm{O}_{2}$ yield used for normalization. (B) TR-MIMS

measurements of substrate $\mathrm{H}_{2}^{16} \mathrm{O} / \mathrm{H}_{2}^{18} \mathrm{O}$ exchange kinetics were performed at $\mathrm{m} / \mathrm{z} 34$ (top plot) for singly-labeled isotopologue ${ }^{16} \mathrm{O}^{18} \mathrm{O}$, and at $\mathrm{m} / \mathrm{z} 36$ (bottom plot) for doubly-labeled ${ }^{18} \mathrm{O}^{18} \mathrm{O}$ in the $\mathrm{S}_{3}$ state in spinach thylakoids at $10^{\circ} \mathrm{C}$ and $\mathrm{pH}$ 6.8. Symbols in both plots are experimental data, and the lines in the top and bottom plots are biexponential and monoexponential fits, respectively. The biexponential fit yields rate constants of $\sim 40 \mathrm{~s}^{-1}$ for the fast phase and $\sim 2 \mathrm{~s}^{-1}$ for the slow phase. The slow phase in the ${ }^{16} \mathrm{O}^{18} \mathrm{O}$ data is matching the rate found in the monoexponential fit of the ${ }^{18} \mathrm{O}^{18} \mathrm{O}$ data (Messinger et al., 1995; Hillier et al., 1998; Hillier and Wydrzynski, 2000, 2004). Adapted from Cox and Messinger (2013).

since they determine the time resolution of the TR-MIMS measurements. In the first $\mathrm{H}_{2}^{16} \mathrm{O} / \mathrm{H}_{2}^{18} \mathrm{O}$-exchange TR-MIMS experiments the water exchange kinetics could not be resolved (Radmer and Ollinger, 1986; Bader et al., 1993). The development of the MIMS cell by Messinger et al. (1995), which allowed for fast mixing of $\mathrm{H}_{2}^{18} \mathrm{O}$ with the sample and also implemented $\mathrm{O}_{2}$ removal from the labeled water by the glucose - glucose oxidase-catalase method, greatly improved the time resolution down to the milliseconds scale and allowed measurements of substrate water 
exchange in all semistable $S_{i}$ states (Messinger et al., 1995; Hillier et al., 1998; Hillier and Wydrzynski, 2000).

Figure 4B illustrates characteristic water exchange kinetics in the $S_{3}$ state as measured in spinach thylakoids with the time resolution of $8 \mathrm{~ms}$. In this figure, the yields of the singly-labeled $\left({ }^{16} \mathrm{O}^{18} \mathrm{O}\right)$ and doubly-labeled $\left({ }^{18} \mathrm{O}^{18} \mathrm{O}\right)$ isotopologues of molecular oxygen are plotted as a function of $\mathrm{H}_{2}^{18} \mathrm{O}$ incubation time in the $S_{3}$ state. While the former plot reflects the result when only one of the two possible ${ }^{18} \mathrm{O}$-water substrates is exchanged, the latter one is for the case when both ${ }^{18} \mathrm{O}$-waters are exchanged. The biphasic behavior of the ${ }^{16} \mathrm{O}^{18} \mathrm{O}$ rise (detected at $\mathrm{m} / \mathrm{z} 34$ ) (see Figure 4B) is known to represent the exchange rates of two independent slowly and fast exchanging substrate water molecules bound at separate sites within the WOC. In contrast, the ${ }^{18} \mathrm{O}^{18} \mathrm{O}$ product (monitored at $\mathrm{m} / \mathrm{z} 36$ ) exhibits a monoexponential rise with a rate equal to that of the slow phase kinetic of the ${ }^{16} \mathrm{O}^{18} \mathrm{O}$ data, thus-reflecting the exchange of the same "slowly" exchanging substrate water as observed at $\mathrm{m} / \mathrm{z} 34$. This finding clearly confirms that the two phases of the ${ }^{16} \mathrm{O}^{18} \mathrm{O}$ data are an intrinsic feature of the WOC and do not originate from PSII heterogeneity (Messinger et al., 1995; Hillier et al., 1998).

Further TR-MIMS experiments also revealed that the "slowly" exchanging water is bound to the WOC in all semi-stable $S_{i}$ states, while the "fast" exchanging water was detected only in the $S_{2}$ and $S_{3}$ states (Hillier et al., 1998; Hillier and Wydrzynski, 2000, 2004; Hendry and Wydrzynski, 2002). Thus, the TR-MIMS technique provides not only the most direct evidence for independent substrate water binding within the WOC, but also allows to monitor the change in their binding affinities throughout the reaction cycle. For a complete overview of the TR-MIMS findings in this field, we refer the readers to reviews by Hillier and Messinger (2005), Hillier and Wydrzynski (2008), Beckmann et al. (2009), Messinger et al. (2012), and Cox and Messinger (2013).

\section{THE ${ }^{16} 0 / /^{18} 0$ ISOTOPE EFFECT AND PHOTOSYNTHETIC WATER-SPLITTING}

Up to now there is no final agreement on whether isotopic discrimination during $\mathrm{O}_{2}$ production by photosynthetic watersplitting in PSII contributes to the so-called Dole effect, which describes the finding that the percentage of the ${ }^{18} \mathrm{O}$ isotope in atmosphere is higher (by 23\%0) than in oceanic waters (Dole, 1936; Tcherkez and Farquhar, 2007). While many gas isotope ratio studies clearly showed that oxygen produced by $\mathrm{O}_{2}$-evolving organisms is isotopically identical to the water they are suspended in (Dole and Jenks, 1944; Stevens et al., 1975; Guy et al., 1993; Helman et al., 2005), recent ${ }^{18} \mathrm{O}$-enriched TR-MIMS experiments indicated that the ${ }^{18} \mathrm{O}$ isotope is favored by the WOC for $\mathrm{O}_{2}$ production, thus-suggesting a significant ${ }^{16} \mathrm{O} /{ }^{18} \mathrm{O}$ isotope effect in the photosynthetic water-splitting (Burda et al., 2001, 2003). This finding was challenged by recent theoretical estimations that suggest a very small isotope effect (Tcherkez and Farquhar, 2007). Undoubtedly, a resolution of these conflicting results can be provided by revisiting TR-MIMS studies. These future studies should be designed to account for: (i) technical limitations/drawbacks of the previous TR-MIMS experiments (for instance, the absence of fast $\mathrm{H}_{2}^{18} \mathrm{O}$ mixing upon its addition to sample suspension inside the MIMS cuvette Bader et al., 1987; Burda et al., 2003), (ii) possible contribution of isotopic fractionation due to transfer of $\mathrm{O}_{2}$ isotopologues through the membrane inlet toward the high vacuum of mass spectrometer recently reported by Hillier et al. (2006), and (iii) current knowledge of the S-state dependent substrate water binding and exchange rates as derived from TR-MIMS measurements (for reviews, see Hillier and Wydrzynski, 2008; Cox and Messinger, 2013). However, we note here, that without specific investigations of the ${ }^{18} \mathrm{O}$ isotope effect in photosynthetic water-oxidation, our TR-MIMS studies do not reveal any oxygen isotope discrimination in photosynthetically produced $\mathrm{O}_{2}$ (for instance, see Figure 6C and text below for explanations), indicating that any such effect must be small at best.

\section{IN SEARCH FOR INTERMEDIATES OF WATER SPLITTING BY TR-MIMS APPROACH}

While most states of the Kok cycle $\left(\mathrm{S}_{0}, \mathrm{~S}_{1}, \mathrm{~S}_{2}, \mathrm{~S}_{3}\right)$ are semistable, the $\mathrm{S}_{3} \mathrm{Y}_{\mathrm{Z}}^{\bullet}$ and $\mathrm{S}_{4}$ state are known to be a highly reactive intermediates that until very recently were not characterized. Clausen and Junge (2004) attempted to stabilize and identify putative intermediate(s) of the $\mathrm{S}_{4}$ state by applying a high partial $\mathrm{O}_{2}$ pressure in order to shift the equilibrium of the terminal $S_{4}$
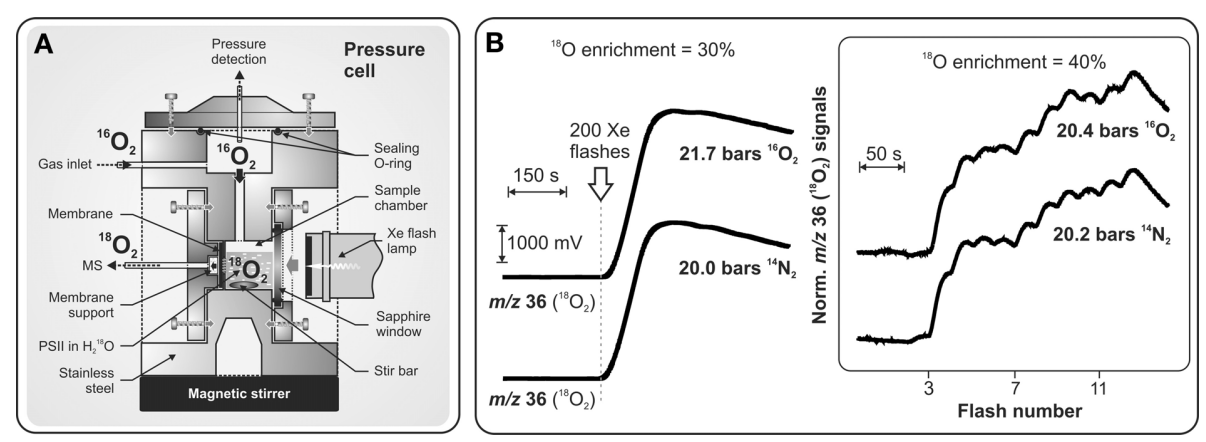

FIGURE 5 | Schematic representation of the pressure cell (A) specially designed for TR-MIMS measurements of light-induced ${ }^{18} \mathrm{O}_{2}$ evolution of PSII under high ${ }^{16} \mathrm{O}_{2} / \mathrm{N}_{2}$ pressures (up to 20 bars). (B) MIMS signals in panel (B); Left: ${ }^{18} \mathrm{O}_{2}$ production of PSII core complexes from Synechocystis sp. PCC 6803 induced by a series of 200 saturating Xenon flashes (given at $2 \mathrm{~Hz}$; indicated by arrow) at 21.7 bars $\mathrm{O}_{2}$, or 20 bars $\mathrm{N}_{2}$.
Other conditions: $30 \% \mathrm{H}_{2}^{18} \mathrm{O}$ enrichment; [Chl] $=50 \mu \mathrm{M} ; 250 \mu \mathrm{M} \mathrm{DCBO}$, $\mathrm{pH} 6.7,20^{\circ} \mathrm{C}$. Right: Flash-induced ${ }^{18} \mathrm{O}_{2}$ evolution patterns of PSII membrane fragments from spinach induced by a series of saturating laser flashes (separated by dark times of $25 \mathrm{~s}$ ) at 20.4 bars $\mathrm{O}_{2}$, or 20.2 bars $\mathrm{N}_{2}$. Other conditions: as above, but with $40 \% \mathrm{H}_{2}^{18} \mathrm{O}$. Adapted from Shevela et al. (2011a). 
$\rightarrow \mathrm{S}_{0}+\mathrm{O}_{2}+n \mathrm{H}^{+}$reaction backwards. Based on their UVabsorption transients the authors observed half suppression of Mn oxidation under only 10 -fold increase of ambient $\mathrm{O}_{2}$ pressure (2.3 bar). These results were considered to be the first indication for an intermediate in the $\mathrm{S}_{3} \rightarrow \mathrm{S}_{4} \rightarrow \mathrm{S}_{0}$ transition and as a possible route for stabilizing it (Clausen and Junge, 2004). Although a further delayed $\mathrm{Chl}$ fluorescence study corroborated these results (Clausen et al., 2005b), experiments by time-resolved X-ray absorption spectroscopy (TR-XAS) (Haumann et al., 2008) and by visible fluorescence study (Kolling et al., 2009) shed doubt on the existence of accessible $S_{4}$ intermediate(s) that can be populated by inhibition of the terminal step of $\mathrm{O}_{2}$ release from the WOC by elevated $\mathrm{O}_{2}$ concentrations. These controversial studies prompted application of the TR-MIMS technique, which allowed investigation of the effect of elevated $\mathrm{O}_{2}$ pressure on photosynthetic $\mathrm{O}_{2}$ release by direct $\mathrm{O}_{2}$ detection (Shevela et al., 2011a). In these experiments direct monitoring of ${ }^{18} \mathrm{O}_{2}$ evolution from ${ }^{18} \mathrm{O}$-labeled water against a high level of ${ }^{16} \mathrm{O}_{2}$ in a suspension of PSII complexes became possible due to a specially designed high pressure MIMS cell (for details, see Figure 5A). This study demonstrated that neither an inhibition nor altered flash-induced pattern of $\mathrm{O}_{2}$ evolution take place under up to 50-fold increased concentration of dissolved $\mathrm{O}_{2}$ around PSII (Figure 5B). These findings show that the terminal water-splitting reaction $/ \mathrm{O}_{2}$ release in PSII is highly exothermic, and are in line with the results obtained by TR-XAS (Haumann et al., 2008) and variable fluorescence (Kolling et al., 2009) studies.

\section{APPLICATIONS IN ARTIFICIAL PHOTOSYNTHESIS}

One of the central goals of artificial photosynthesis is the development of bio-inspired, efficient and robust catalysts that are able to split water employing the energy of sunlight in a fashion similar to the water-oxidizing $\mathrm{Mn}_{4} \mathrm{CaO}_{5}$ cluster in PSII (Concepcion et al., 2012; Nocera, 2012; Wiechen et al., 2012). Therefore, data concerning catalytic rates and turnover numbers (stability) of newly synthetized $\mathrm{O}_{2}$-evolving catalysts are highly important for their further development. In this regard, in addition to traditionally used amperometric methods for $\mathrm{O}_{2}$ detection (Renger and Hanssum, 2009), TR-MIMS can be applied as a highly sensitive method for studying the $\mathrm{O}_{2}$-evolving capability of these complexes. However, a major advantage and uniqueness of the TR-MIMS technique in this field is that, in combination with ${ }^{18} \mathrm{O}$-labeling experiments, it can be employed for studying the pathways of $\mathrm{O}_{2}$ formation in reactions catalyzed by the 'potential' solar water-oxidation catalysts (Poulsen et al., 2005; Beckmann et al., 2008; Sala et al., 2010; Shevela et al., 2011b; Najafpour et al., 2012; Vigara et al., 2012). Thus, TR-MIMS detection of the isotopologues of $\mathrm{O}_{2}\left({ }^{16} \mathrm{O}_{2},{ }^{16} \mathrm{O}^{18} \mathrm{O},{ }^{18} \mathrm{O}_{2}\right)$ during catalytic $\mathrm{O}_{2}$-formation in the ${ }^{18} \mathrm{O}$-enriched aqueous solutions allows to analyze the ${ }^{18} \mathrm{O}$-fraction $\left({ }^{18} \alpha\right)$ of the evolved $\mathrm{O}_{2}$ with good time resolution and very high accuracy. A correlation of the ${ }^{18} \mathrm{O}$-fraction in the substrate water $\left({ }^{18} \alpha_{\text {theor }}\right.$; reflects the $\mathrm{H}_{2}^{18} \mathrm{O}$ enrichment of the solvent water) and in the product $\mathrm{O}_{2}\left({ }^{18} \alpha_{\mathrm{exp}}\right)$ gives important information about the origin of the $\mathrm{O}$ atoms in the produced molecular oxygen. For instance, the incorporation of exactly half of the possible ${ }^{18} \mathrm{O}$-fraction into the evolved $\mathrm{O}_{2}$ may indicate that only one of the two $\mathrm{O}$ atoms of the $\mathrm{O}_{2}$ product
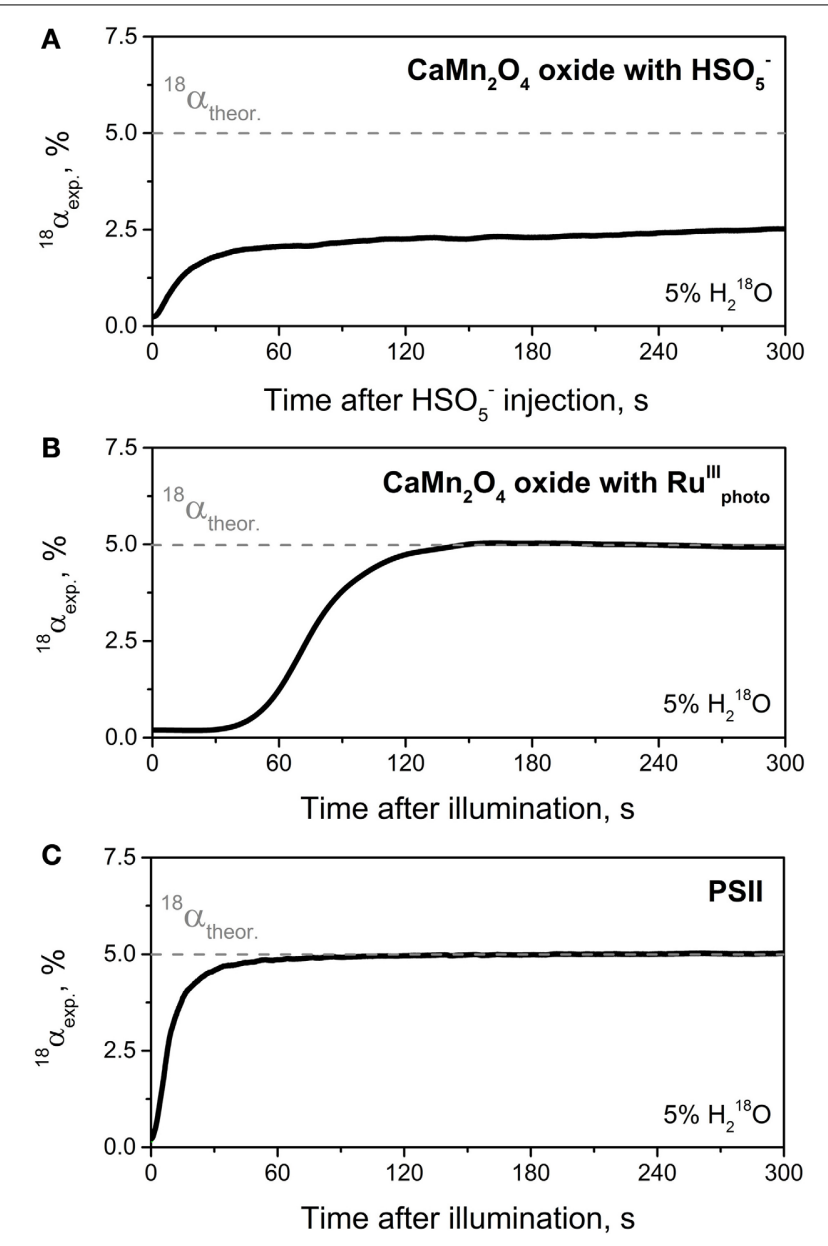

FIGURE 6 | Development of the ${ }^{18} \mathrm{O}$-isotope fraction $\left({ }^{18} \alpha\right)$ over time for the course of the catalytic $\mathrm{O}_{2}$-formation in reactions catalyzed by synthesized $\mathrm{CaMn}_{2} \mathrm{O}_{4} \cdot \mathrm{H}_{2} \mathrm{O}$ oxide (A,B) and by the WOC of PSII (C). (A)

Change in ${ }^{18} \alpha$-value for the reaction of $\mathrm{CaMn}_{2} \mathrm{O}_{4} \cdot \mathrm{H}_{2} \mathrm{O}$ with $\mathrm{HSO}_{5}^{-}$(oxone) indicating that only one of the two oxygen atoms of $\mathrm{O}_{2}$ evolved originates from the bulk water. A solution of $\mathrm{HSO}_{5}^{-}$in $\mathrm{H}_{2}^{18} \mathrm{O}$-enriched water was injected at $t=0$ into the MIMS cell filled in with a non-enriched oxide suspension $11 \mathrm{mg}$ $\left.\mathrm{ml}^{-1} ; \mathrm{pH} \sim 4.5\right)$ to give a final $\mathrm{HSO}_{5}^{-}$concentration of $3.7 \mathrm{mM}$ and an $\mathrm{H}_{2}^{18} \mathrm{O}$ enrichment of $5 \%$. Note that the rise of ${ }^{18} \alpha$ to the value of $2.5 \%$ corresponds to half the percentage of the ${ }^{18} \mathrm{O}$-labeled water. (B) Change in ${ }^{18} \alpha$-value for the reaction of $\mathrm{CaMn}_{2} \mathrm{O}_{4} \cdot \mathrm{H}_{2} \mathrm{O}$ with photogenerated $\left[\mathrm{Ru}^{\mathrm{III}}(\text { bipy) })_{3}\right]^{3+}$. Shortly before illumination (started at $t=0)$ the reaction mixture $\left(\mathrm{H}_{2}^{18} \mathrm{O}(5 \%)\right.$, $\mathrm{CaMn}_{2} \mathrm{O}_{4} \cdot \mathrm{H}_{2} \mathrm{O}\left(1 \mathrm{mg} \mathrm{ml}^{-1}\right)$, $\left[\mathrm{Ru}(\text { bipy })_{3}\right]^{2+}(1.5 \mathrm{mM})$, and $\left[\mathrm{Co}\left(\mathrm{NH}_{3}\right)_{5} \mathrm{Cl}\right]^{2+}$ $(12.5 \mathrm{mM})$; $\mathrm{pH} \sim 4$ ) inside the MIMS cell was purged with $\mathrm{N}_{2}$ until "zero" $\mathrm{O}_{2}$ level was reached. (C) Change in ${ }^{18} \alpha$-value for $\mathrm{O}_{2}$ production by PSII membrane fragments isolated from spinach. $\mathrm{O}_{2}$ evolution was induced by actinic continuous light at $t=0$. Other conditions: $5 \% \mathrm{H}_{2}^{18} \mathrm{O},[\mathrm{Chl}]=0.03 \mathrm{mg}$ $\mathrm{ml}^{-1}, 0.6 \mathrm{mM} \mathrm{PPBQ}, 2 \mathrm{mM} \mathrm{K}_{3}\left[\mathrm{Fe}(\mathrm{CN})_{6}\right], \mathrm{pH} 6.0$, and $20^{\circ} \mathrm{C}$. Gray dashed lines in all panels indicates the theoretical ${ }^{18} \alpha$ value expected for reaction of the "true" water-splitting, i.e., when both oxygen atoms of formed $\mathrm{O}_{2}$ originate from water. In all cases $\mathrm{O}_{2}$ production was detected by TR-MIMS as ${ }^{16} \mathrm{O}_{2}$ (at $\mathrm{m} / \mathrm{z} 32),{ }^{16} \mathrm{O}^{18} \mathrm{O}(\mathrm{m} / \mathrm{z} 34)$, and ${ }^{18} \mathrm{O}_{2}(\mathrm{~m} / \mathrm{z} 36)$, and the ${ }^{18} \alpha$ was calculated according to the following equation: ${ }^{18} \alpha=\left(\left[{ }^{18} \mathrm{O}_{2}\right]+1 / 2\left[{ }^{16} \mathrm{O}^{18} \mathrm{O}\right]\right) /\left[\mathrm{O}_{2}\right]_{\text {total }}$. Adapted from Shevela et al. (2011b).

originates from the bulk water as it has been monitored by TR-MIMS in the reactions of $\mathrm{O}_{2}$-evolving catalysts with oxygentransferring oxidizing agent, oxone ( $\mathrm{HSO}_{5}^{-}$) (Poulsen et al., 2005; Beckmann et al., 2008; Shevela et al., 2011b) (see Figure 6A). In 
the case of "true" water-splitting, ${ }^{18} \mathrm{O}$-fractions in bulk water and in evolved $\mathrm{O}_{2}$ are expected to be same (i.e., ${ }^{18} \alpha_{\text {theor }}={ }^{18} \alpha_{\exp }$ ) as depicted in Figure 6B for the reaction of a synthetic catalyst $\left(\mathrm{CaMn}_{2} \mathrm{O}_{4} \cdot \mathrm{H}_{2} \mathrm{O}\right.$ oxide $)$ with photogenerated oxidizing agent $\left[\mathrm{Ru}^{\mathrm{III}}(\text { bipy })_{3}\right]^{3+}\left(\mathrm{Ru}_{\text {photo }}^{\mathrm{III}}\right)$, and in Figure 6C for natural lightinduced water-splitting reaction performed by PSII. It's worth mentioning here, that the initial phase of the presented traces until stable ${ }^{18} \alpha$ values (Figure 6) is a technical artefact, merely caused by the response time of the membrane-inlet system of the mass spectrometer which seems to be related to the overall $\mathrm{O}_{2}$ concentration. However, the difference in time needed to reach final ${ }^{18} \alpha$ value in two water-splitting reactions shown in Figure 6 also reflects a much slower reaction rate for the reaction of the oxide with $\mathrm{Ru}_{\text {photo }}^{\mathrm{III}}$. Thus, $\mathrm{O}_{2}$ evolution for this reaction was detected only after $1 \mathrm{~min}$ of illumination since this time is required to build up a sufficient concentration of photosensitizer $\mathrm{Ru}$ photo (data not shown here; for details, see Shevela et al., 2011b). We note that one of the attractive extensions to the described TR-MIMS approach for the characterization of watersplitting catalysts is the coupling of the TR-MIMS instrument to an electrochemical cell (for further details, see Konermann et al., 2008 and refs therein).

\section{CONCLUSIONS AND FUTURE PERSPECTIVES}

Application of the TR-MIMS technique and isotope labeling for studies of various biophysical aspects of photosynthetic watersplitting and $\mathrm{O}_{2}$ production is continuously growing. It provides not only insightful and unique information (which is sometimes not accessible by other methods) about this fundamental biological process, but also becomes an essential and highly precise tool for testing artificial water-oxidizing catalysts. Future applications of TR-MIMS for studies of watersplitting chemistry and $\mathrm{O}_{2}$ production could follow from advances in membrane materials, different designs of the membrane-inlet systems, coupling with electrochemistry and spectroscopy, and technological developments of the mass spectrometers.

\section{ACKNOWLEDGMENTS}

The authors acknowledge financial support by the Kempe Foundation, the Swedish Research Council, the Energimyndigheten, the Strong Research Environment Solar Fuels (Umeå University), and the Artificial Leaf Project (K\&A Wallenberg Foundation).

\section{REFERENCES}

Aartsma, T. J., and Matysik, J. (eds.). (2008). Biophysical Techniques in Photosynthesis. Dordrecht: Springer. doi: 10.1007/978-1-4020-8250-4

Aoyama, C., Suzuki, H., Sugiura, M., and Noguchi, T. (2008). Flash-induced FTIR difference spectroscopy shows no evidence for the structural coupling of bicarbonate to the oxygen-evolving Mn cluster in photosystem II. Biochemistry 47, 2760-2765. doi: 10.1021/bi702241t

Bader, K. P., Renger, G., and Schmid, G. H. (1993). A mass-spectrometric analysis of the water splitting reaction. Photosynth. Res. 38, 355-361. doi: 10.1007/BF00046761

Bader, K. P., Thibault, P., and Schmid, G. H. (1987). Study on the properties of the $S_{3}$ state by mass-spectrometry in the filamentous cyanobacterium Oscillatoria chalybea. Biochim. Biophys. Acta 893, 564-571. doi: 10.1016/00052728(87)90108-3
Beckmann, K., Messinger, J., Badger, M. R., Wydrzynski, T., and Hillier, W. (2009). On-line mass spectrometry: membrane inlet sampling. Photosynth. Res. 102, 511-522. doi: 10.1007/s11120-009-9474-7

Beckmann, K., Uchtenhagen, H., Berggren, G., Anderlund, M. F., Thapper, A., Messinger, J., et al. (2008). Formation of stoichiometrically ${ }^{18} \mathrm{O}$-labelled oxygen from the oxidation of ${ }^{18} \mathrm{O}$-enriched water mediated by a dinuclear manganese complex-a mass spectrometry and EPR study. Energy Environ. Sci. 1, 668-676. doi: 10.1039/b811806

Burda, K., Bader, K. P., and Schmid, G. H. (2001). An estimation of the size of the water cluster present at the cleavage site of the water splitting enzyme. FEBS Lett. 491, 81-84. doi: 10.1016/S0014-5793(01)02175-5

Burda, K., Bader, K. P., and Schmid, G. H. (2003). ${ }^{18} \mathrm{O}$ isotope effect in the photosynthetic water splitting process. Biochim. Biophys. Acta 1557, 77-82. doi: 10.1016/S0005-2728(02)00395-X

Clausen, J., Beckmann, K., Junge, W., and Messinger, J. (2005a). Evidence that bicarbonate is not the substrate in photosynthetic oxygen evolution. Plant Physiol. 139, 1444-1450. doi: 10.1104/pp.105.068437

Clausen, J., Junge, W., Dau, H., and Haumann, M. (2005b). Photosynthetic water oxidation at high $\mathrm{O}_{2}$ backpressure monitored by delayed chlorophyll fluorescence. Biochemistry 44, 12775-12779. doi: 10.1021/bi051183a

Clausen, J., and Junge, W. (2004). Detection of an intermediate of photosynthetic water oxidation. Nature 430, 480-483. doi: 10.1038/nature02676

Concepcion, J. J., House, R. L., Papanikolas, J. M., and Meyer, T. J. (2012). Chemical approaches to artificial photosynthesis. Proc. Natl. Acad. Sci. U.S.A. 109, 15560-15564. doi: 10.1073/pnas.1212254109

Cox, N., and Messinger, J. (2013). Reflections on substrate water and dioxygen formation. Biochim. Biophys. Acta 1827, 1020-1030. doi: 10.1016/j.bbabio.2013.01.013

Dasgupta, J., Ananyev, G. M., and Dismukes, G. C. (2008). Photoassembly of the water-oxidizing complex in photosystem II. Coord. Chem. Rev. 252, 347-360. doi: 10.1016/j.ccr.2007.08.022

Davey, N. G., Krogh, E. T., and Gill, C. G. (2011). Membrane-introduction mass spectrometry (MIMS). Trends Anal. Chem. 30, 1477-1485. doi: 10.1016/j.trac.2011.05.003

Diner, B. A., and Rappaport, F. (2002). Structure, dynamics, and energetics of the primary photochemistry of photosystem II of oxygenic photosynthesis. Annu. Rev. Plant Biol. 53, 551-580. doi: 10.1146/annurev.arplant.53.100301.135238

Dole, M. (1936). The relative atomic weight of oxygen in water and in air. J. Chem. Phys. 4, 268-275. doi: 10.1063/1.1749834

Dole, M., and Jenks, G. (1944). Isotopic composition of photosynthetic oxygen. Science 3, 409. doi: 10.1126/science.100.2601.409

Ferreira, K. N., Iverson, T. M., Maghlaoui, K., Barber, J., and Iwata, S. (2004). Architecture of the photosynthetic oxygen-evolving center. Science 303, 1831-1838. doi: 10.1126/science. 1093087

Feyziev, Y. M., Yoneda, D., Yoshii, T., Katsuta, N., Kawamori, A., and Watanabe, Y. (2000). Formate-induced inhibition of the water-oxidizing complex of photosystem II studied by EPR. Biochemistry 39, 3848-3855. doi: 10.1021/bi992479h

Govindjee, Weger, H. G., Turpin, D. H., Van Rensen, J. J. S., Devos, O. J., and Snel, J. F. H. (1991). Formate releases carbon dioxide/bicarbonate from thylakoid membranes - measurements by mass spectroscopy and infrared gas analyzer. Naturwissenschaften 78, 168-170. doi: 10.1007/BF01136204

Guskov, A., Gabdulkhakov, A., Broser, M., Glöckner, C., Hellmich, J., Kern, J., et al. (2010). Recent progress in the crystallographic studies of photosystem II. ChemPhysChem 11, 1160-1171. doi: 10.1002/cphc.200900901

Guy, R. D., Fogel, M. L., and Berry, J. A. (1993). Photosynthetic fractionation of the stable isotopes of oxygen and carbon. Plant Physiol. 101, 37-47.

Haumann, M., Grundmeier, A., Zaharieva, I., and Dau, H. (2008). Photosynthetic water oxidation at elevated dioxygen partial pressure monitored by timeresolved X-ray absorption measurements. Proc. Natl. Acad. Sci. U.S.A. 105, 17384-17389. doi: 10.1073/pnas.0802596105

Helman, Y., Barkan, E., Eisenstadt, D., Luz, B., and Kaplan, A. (2005). Fractionation of the three stable oxygen isotopes by oxygen-producing and oxygen-consuming reactions in photosynthetic organisms. Plant Physiol. 138, 2292-2298. doi: 10.1104/pp.105.063768

Hendry, G., and Wydrzynski, T. (2002). The two substrate water molecules are already bound to the oxygen evolving complex in the $\mathrm{S}_{2}$ state of photosystem II. Biochemistry 41, 13328-13334. doi: 10.1021/bi026246t

Hillier, W., McConnell, I., Badger, M. R., Boussac, A., Klimov, V. V., Dismukes, G. C., et al. (2006). Quantitative assessment of intrinsic carbonic anhydrase activity 
and the capacity for bicarbonate oxidation in photosystem II. Biochemistry 45, 2094-2102. doi: 10.1021/bi051892o

Hillier, W., Messinger, J., and Wydrzynski, T. (1998). Kinetic determination of the fast exchanging substrate water molecule in the $\mathrm{S}_{3}$ state of photosystem II. Biochemistry 37, 16908-16914. doi: 10.1021/bi980756z

Hillier, W., and Messinger, J. (2005). "Mechanism of photosynthetic oxygen production," in Photosystem II. The Light-Driven Water:Plastoquinone Oxidoredutase, eds T. Wydrzynski and K. Satoh (Dordrecht: Springer), 567-608.

Hillier, W., and Wydrzynski, T. (2000). The affinities for the two substrate water binding sites in the $\mathrm{O}_{2}$ evolving complex of photosystem II vary independently during S-state turnover. Biochemistry 39, 4399-4405. doi: 10.1021/bi992318d

Hillier, W., and Wydrzynski, T. (2004). Substrate water interactions within the photosystem II oxygen evolving complex. Phys. Chem. Chem. Phys. 6, 4882-4889. doi: $10.1039 / \mathrm{b} 407269 \mathrm{c}$

Hillier, W., and Wydrzynski, T. (2008). ${ }^{18} \mathrm{O}$-Water exchange in photosystem II: Substrate binding and intermediates of the water splitting cycle. Coord. Chem. Rev. 252, 306-317. doi: 10.1016/j.ccr.2007.09.004

Hoch, G., and Kok, B. (1963). A mass spectrometer inlet system for sampling gases dissolved in liquid phases. Arch. Biochem. Biophys. 101, 160-170. doi: 10.1016/0003-9861(63)90546-0

Ishikita, H., Loll, B., Biesiadka, J., Saenger, W., and Knapp, E.-W. (2005). Redox potentials of chlorophylls in the photosystem II reaction center. Biochemistry 44, 4118-4124. doi: 10.1021/bi047922p

Johnson, R. C., Cooks, R. G., Allen, T. M., Cisper, M. E., and Hemberger, P. H. (2000). Membrane introduction mass spectrometry: Trends and applications. Mass Spectrom. Rev. 19, 1-37. doi: 10.1002/(SICI)10982787(2000)19:1<1::AID-MAS1>3.0.CO;2-Y

Kok, B., Forbush, B., and McGloin, M. (1970). Cooperation of charges in photosynthetic $\mathrm{O}_{2}$ evolution. Photochem. Photobiol. 11, 457-476. doi: 10.1111/j.17511097.1970.tb06017.x

Kolling, D. R. J., Brown, T. S., Ananyev, G., and Dismukes, G. C. (2009). Photosynthetic oxygen evolution is not reversed at high oxygen pressures: mechanistic consequences for the water-oxidizing complex. Biochemistry 48 1381-1389. doi: 10.1021/bi801774f

Konermann, L., Messinger, J., and Hillier, W. (2008). "Mass spectrometry based methods for studying kinetics and dynamics in biological systems," in Biophysical Techniques in Photosynthesis, eds J. Amesz and A. J. Hoff (Dordrecht: Springer), 167-190. doi: 10.1007/978-1-4020-8250-4_9

Lauritsen, F. R., and Kotiaho, T. (1996). Advances in membrane inlet mass spectrometry (MIMS). Rev. Anal. Chem. 15, 237-264. doi: 10.1515/REVAC.1996.15.4.237

Lu, Y. K., and Stemler, A. J. (2002). Extrinsic photosystem II carbonic anhydrase in maize mesophyll chloroplasts. Plant Physiol. 128, 643-649. doi: 10.1104/pp.010643

McConnell, I. L., Badger, M. R., Wydrzynski, T., and Hillier, W. (2007). A quantitative assessment of the carbonic anhydrase activity in photosystem II. Biochim. Biophys. Acta 1767, 639-647. doi: 10.1016/j.bbabio.2007.01.019

Messinger, J., Alia, A., and Govindjee, (2009a). Special educational issue on "Basics and application of biophysical techniques in photosynthesis and related processes." Photosynth. Res. 101, 89-92. doi: 10.1007/s11120-009-9471-x

Messinger, J., Alia, A., and Govindjee, (2009b). Special educational issue on "Basics and application of biophysical techniques in photosynthesis and related processes”-Part B. Photosynth. Res. 102, 103-106. doi: 10.1007/s11120-0099494-3

Messinger, J., Badger, M. R., and Wydrzynski, T. (1995). Detection of one slowly exchanging substrate water molecule in the $\mathrm{S}_{3}$ state of photosystem II. Proc. Natl. Acad. Sci. U.S.A. 92, 3209-3213. doi: 10.1073/pnas.92.8.3209

Messinger, J., Noguchi, T., and Yano, J. (2012). "Photosynthetic O2 evolution," in Molecular Solar Fuels, eds T. Wydrzynski and W. Hillier (Cambridge: RSC Publishing), 163-207.

Metzner, H. (1978). Photosynthetic Oxygen Evolution. London: Academic Press.

Moskvin, O. V., Shutova, T. V., Khristin, M. S., Ignatova, L. K., Villarejo, A., Samuelsson, G., et al. (2004). Carbonic anhydrase activities in pea thylakoidsA photosystem II core complex-associated carbonic anhydrase. Photosynth. Res. 79, 93-100. doi: 10.1023/B:PRES.0000011925.93313.db

Najafpour, M. M., Hillier, W., Shamkhali, A. N., Amini, M., Beckmann, K., Jaglicic, Z., et al. (2012). Synthesis, characterization, DFT studies and catalytic activities of manganese(ii) complex with 1,4-bis $\left(2,2^{\prime}: 6,2^{\prime \prime}\right.$-terpyridin- $4^{\prime}$-yl) benzene. Dalton Trans. 41, 12282-12288. doi: 10.1039/c2dt31544k
Nocera, D. G. (2012). The artificial leaf. Acc. Chem. Res. 45, 767-776. doi: $10.1021 / \operatorname{ar} 2003013$

Poulsen, A. K., Rompel, A., and McKenzie, C. J. (2005). Water oxidation catalyzed by a dinuclear Mn complex: a functional model for the oxygenevolving center of photosystem II. Angew. Chem. Int. Ed. 44, 6916-6920. doi: 10.1002/anie. 200502114

Radmer, R., and Ollinger, O. (1980). Isotopic composition of photosynthetic $\mathrm{O}_{2}$ flash yields in the presence of $\mathrm{H}_{2}^{18} \mathrm{O}$ and $\mathrm{HC}^{18} \mathrm{O}_{3}^{-}$. FEBS Lett. 110, 57-61. doi: 10.1016/0014-5793(80)80022-6

Radmer, R., and Ollinger, O. (1986). Do the higher oxidation states of the photosynthetic $\mathrm{O}_{2}$ evolving system contain bound water? FEBS Lett. 195, 285-289. doi: 10.1016/0014-5793(86)80178-8

Renger, G., and Hanssum, B. (2009). Oxygen detection in biological systems. Photosynth. Res. 102, 487-498. doi: 10.1007/s11120-009-9434-2

Ruben, S., Randall, M., Kamen, M., and Hyde, J. L. (1941). Heavy oxygen $\left(\mathrm{O}^{18}\right)$ as a tracer in the study of photosynthesis. J. Am. Chem. Soc. 63, 877-879. doi: 10.1021/ja01848a512

Sala, X., Ertem, M. Z., Vigara, L., Todorova, T. K., Chen, W., Rocha, R. C. et al. (2010). The cis- $\left[\mathrm{RuII}(\mathrm{bpy})_{2}\left(\mathrm{H}_{2} \mathrm{O}\right)_{2}\right]^{2+}$ water-oxidation catalyst revisited. Angew. Chem. Int. Ed. 49, 7745-7747. doi: 10.1002/anie.201002398

Shevela, D., Beckmann, K., Clausen, J., Junge, W., and Messinger, J. (2011a). Membrane-inlet mass spectrometry reveals a high driving force for oxygen production by photosystem II. Proc. Natl. Acad. Sci. U.S.A. 108, 3602-3607. doi: $10.1073 /$ pnas. 1014249108

Shevela, D., Koroidov, S., Najafpour, M. M., Messinger, J., and Kurz, P. (2011b). Calcium manganese oxides as oxygen evolution catalysts: $\mathrm{O}_{2}$ formation pathways indicated by ${ }^{18} \mathrm{O}$-labelling studies. Chem. Eur. J. 17, 5415-5423. doi: 10.1002/chem. 201002548

Shevela, D., Klimov, V., and Messinger, J. (2008a). "Formate-induced release of carbon dioxide/hydrogencarbonate from photosystem II," in Photosynthesis. Energy From the Sun, eds J. F. Allen, E. Gantt, J. H. Golbeck, and B. Osmond (Glasgow: Springer), 497-501.

Shevela, D., Su, J. H., Klimov, V., and Messinger, J. (2008b). Hydrogencarbonate is not a tightly bound constituent of the water-oxidizing complex in photosystem II. Biochim. Biophys. Acta 1777, 532-539. doi: 10.1016/j.bbabio.2008.03.031

Stemler, A. (1989). Absence of a formate-induced release of bicarbonate from photosystem 2. Plant Physiol. 91, 287-290. doi: 10.1104/pp.91.1.287

Stemler, A., and Radmer, R. (1975). Source of photosynthetic oxygen in bicarbonate-stimulated Hill reaction. Science 190, 457-458. doi: 10.1126/science.190.4213.457

Stevens, C. L. R., Schultz, D., Van Baalen, C., and Parker, P. L. (1975). Oxygen isotope fractionation during photosynthesis in a blue-green and areen alga. Plant Physiol. 56, 126-129. doi: 10.1104/pp.56.1.126

Tcherkez, G., and Farquhar, G. D. (2007). On the ${ }^{16} \mathrm{O} /{ }^{18} \mathrm{O}$ isotope effect associated with photosynthetic $\mathrm{O}_{2}$ production. Funct. Plant Biol. 34, 1049-1052. doi: 10.1071/FP07168

Ulas, G., Olack, G., and Brudvig, G. W. (2008). Evidence against bicarbonate bound in the $\mathrm{O}_{2}$-evolving complex of photosystem II. Biochemistry 47, 3073-3075. doi: 10.1021/bi8000424

Umena, Y., Kawakami, K., Shen, J.-R., and Kamiya, N. (2011). Crystal structure of oxygen-evolving photosystem II at a resolution of $1.9 \AA$. Nature $473,55-60$. doi: 10.1038 /nature09913

Van Rensen, J. J. S., and Klimov, V. V. (2005). "Bicarbonate interactions," in Photosystem II. The Light-Driven Water:Plastoquinone Oxidoreductase, eds T Wydrzynski and K. Satoh (Dordrecht: Springer), 329-346.

Vigara, L., Ertem, M. Z., Planas, N., Bozoglian, F., Leidel, N., Dau, H., et al. (2012). Experimental and quantum chemical characteriazation of the water oxidation cycle catalysed by $\left[\mathrm{Ru}^{\mathrm{II}}(\mathrm{damp})(\mathrm{bpy})\left(\mathrm{H}_{2} \mathrm{O}\right)\right]^{2+}$. Chem. Sci. 3, 2576-2586. doi: $10.1039 / \mathrm{c} 2 \mathrm{sc} 20399 \mathrm{e}$

Villarejo, A., Shutova, T., Moskvin, O., Forssen, M., Klimov, V. V., and Samuelsson, G. (2002). A photosystem II-associated carbonic anhydrase regulates the efficiency of photosynthetic oxygen evolution. EMBO J. 21, 1930-1938. doi: 10.1093/emboj/21.8.1930

Vinyard, D. J., Ananyev, G. M., and Dismukes, G. C. (2013). Photosystem II: the reaction center of oxygenic photosynthesis*. Annu. Rev. Biochem. 82, 577-606. doi: 10.1146/annurev-biochem-070511-100425

Wiechen, M., Berends, H.-M., and Kurz, P. (2012). Water oxidation catalysed by manganese compounds: from complexes to 'biomimetic rocks'. Dalton Trans. 41, 21-31. doi: 10.1039/c1dt11537e 
Wydrzynski, T., Hillier, W., and Messinger, J. (1996). On the functional significance of substrate accessibility in the photosynthetic water oxidation mechanism. Physiol. Plant. 96, 342-350. doi: 10.1111/j.1399-3054.1996. tb00224.x

Yano, J., Kern, J., Sauer, K., Latimer, M. J., Pushkar, Y., Biesiadka, J., et al. (2006). Where water is oxidized to dioxygen: structure of the photosynthetic $\mathrm{Mn}_{4} \mathrm{Ca}$ cluster. Science 314, 821-825. doi: 10.1126/science. 1128186

Conflict of Interest Statement: The authors declare that the research was conducted in the absence of any commercial or financial relationships that could be construed as a potential conflict of interest.
Received: 04 October 2013; accepted: 01 November 2013; published online: 26 November 2013.

Citation: Shevela D and Messinger J (2013) Studying the oxidation of water to molecular oxygen in photosynthetic and artificial systems by time-resolved membrane-inlet mass spectrometry. Front. Plant Sci. 4:473. doi: 10.3389/fpls.2013.00473

This article was submitted to Plant Physiology, a section of the journal Frontiers in Plant Science.

Copyright (c) 2013 Shevela and Messinger. This is an open-access article distributed under the terms of the Creative Commons Attribution License (CC BY). The use, distribution or reproduction in other forums is permitted, provided the original author(s) or licensor are credited and that the original publication in this journal is cited, in accordance with accepted academic practice. No use, distribution or reproduction is permitted which does not comply with these terms. 